\title{
Increased oxidation of extracellular glutathione by bronchoalveolar inflammatory cells in diffuse fibrosing alveolitis
}

\author{
J. Behr*, B. Degenkolb*, K. Maier**, B. Braun*, T. Beinert*, F. Krombach+, \\ C. Vogelmeier*, G. Fruhmann*
}

Increased oxidation of extracellular glutathione by bronchoalveolar inflammatory cells in diffuse fibrosing alveolitis. J. Behr, B. Degenkolb, K. Maier, B. Braun, T. Beinert, F. Krombach, C. Vogelmeier, G. Fruhmann. @ERS Journals Ltd 1995.

ABSTRACT: An unbalanced oxidative stress is thought to be an important element in the pathogenesis of diffuse fibrosing alveolitis (DFA). The purpose of our study was to investigate the role of reactive oxygen metabolites (ROMs) released from cultured bronchoalveolar inflammatory cells (BA-cells) on glutathione oxidation. We studied bronchoalveolar lavage samples from 10 healthy controls and from 20 patients with diffuse fibrosing alveolitis (all were nonsmokers).

BA-cells obtained by bronchoalveolar lavage (BAL) were incubated with $50 \mu \mathrm{M}$ of reduced glutathione (GSH). Oxidation of GSH to glutathione disulphide (GSSG) by BA-cell derived oxidants was detected as a decline of GSH in the supernatants. Total glutathione (GSHtot $=$ GSH +2 GSSG) and GSSG in the epithelial lining fluid $(\mathrm{ELF})$, and methionine sulphoxide $(\operatorname{Met}(\mathrm{O}))$ content of BAL proteins were determined.

In diffuse fibrosing alveolitis the oxidative activity of BA-cells was enhanced, GSHtot and GSH were decreased, whereas the GSSG:GSH ratio was increased. The oxidative activity of BA-cells correlated positively with the GSSG:GSH ratio, but not with the methionine sulphoxide content. The methionine sulphoxide content was elevated in diffuse fibrosing alveolitis and inversely correlated with GSHtot. The methionine sulphoxide content also correlated positively with the percentage of BAL neutrophils.

We conclude that BA-cell-derived reactive oxygen species are capable of oxidizing extracellular GSH in vitro. The positive correlation between the BA-cell oxidative activity in vitro and GSSG:GSH ratio in ELF suggests that a similar oxidative effect on extracellular GSH may also occur in vivo. Thus, reactive oxygen metabolites released from BA-cells may contribute to a lowered antioxidant screen, thereby causing oxidative damage of other molecules, as indicated by an increase of methionine sulphoxide content.

Eur Respir J., 1995, 8, 1286-1292.
*Pneumologische Abteilung, Medizinische Klinik I, Klinikum Großhadern, University of Munich, Germany. **GSF Forschungszentrum für Umwelt und Gesundheit, Neuherberg, Germany. +Institut für Chirurgische Forschung, Klinikum Großhadern, University of Munich, Germany.

Correspondence: J. Behr Pneumologische Abteilung Medizinische Klinik I

Klinikum Großhadern der Universität Marchioninistraße 15

81377 München

Germany

Keywords: Bronchoalveolar inflammatory cells

fibrosing alveolitis

glutathione

lung injury

oxidants

Received: August 121994

Accepted after revision April 111995

This work was supported by a grant from the Wilhelm Sander-Stiftung to J.B. (No. 92.036.1)

The data were presented in part at the ATS/ ALA International Conference, May 1994, Boston.
The nicotinamide-adenine-dinucleotide phosphate (NADPH) oxidase of activated inflammatory cells, such as macrophages and neutrophils, produces superoxide anions which are transformed into a variety of reactive oxygen metabolites (ROMs): hydrogen peroxide, hydroxyl radicals and hypohalide anions [1-3]. These reactive oxygen species are capable of inducing cell damage as well as lesions of the extracellular tissue compounds [4-7]. Therefore, toxic oxygen products have been claimed to play a prominent role in the pathogenesis of chronic inflammatory lung diseases [8-11]. Moreover, the antioxidant screen of the extracellular compartment of the lung with reduced glutathione (GSH) as the key molecule is impaired in patients with idiopathic pulmonary fibrosis [12-14], and GSH deficiency may aggravate oxidative tissue injury in this disease. However, the antioxidant effect of GSH has not yet been demonstrated in the human lung in vivo.

The goal of the present study was to measure extracellular GSH oxidation by ROMs released from inflammatory cells of the lower respiratory tract. The results were compared to glutathione concentrations and redox balance in the epithelial lining fluid (ELF), in order to test the hypothesis that ROMs released from bronchoalveolar inflammatory cells (BA-cells) contribute to an impairment of the antioxidant capacity of the lung, thereby potentially aggravating oxidant injury. Oxidative stress was assessed by quantifying the methionine sulphoxide content of proteins contained in ELF [11, 15, $16]$. 
Table 1. - Clinical and lung function characteristics of control subjects and patients with DFA

\begin{tabular}{|c|c|c|}
\hline & $\begin{array}{c}\text { Control group } \\
n=10\end{array}$ & $\begin{array}{c}\text { DFA patients } \\
\mathrm{n}=20\end{array}$ \\
\hline Age yrs & $30 \pm 3$ & $64 \pm 2 *$ \\
\hline Gender $\mathrm{M} / \mathrm{F}$ & $5 / 5$ & $7 / 13$ \\
\hline Vital capacity $\%$ pred & $103 \pm 3$ & $77 \pm 4 *$ \\
\hline Total lung capacity $\%$ pred & $98 \pm 5$ & $75 \pm 4 *$ \\
\hline Transfer factor $\%$ pred & $104 \pm 5$ & $51 \pm 3 *$ \\
\hline \multirow{2}{*}{$\begin{array}{ll}\text { Resting } \mathrm{Pa}, \mathrm{O}_{2} & \begin{array}{l}\mathrm{kPa} \\
\mathrm{mmHg}\end{array}\end{array}$} & $11.4 \pm 0.3$ & $9.9 \pm 0.3 *$ \\
\hline & $85.5 \pm 2.5$ & $74.1 \pm 2.3^{*}$ \\
\hline \multirow{2}{*}{$\begin{array}{ll}\text { Exercise } \mathrm{Pa}, \mathrm{O}_{2} & \mathrm{kPa} \\
& \mathrm{mmHg}\end{array}$} & $12.0 \pm 0.3$ & $8.7 \pm 0.6^{*}$ \\
\hline & $89.9 \pm 2.1$ & $65.4 \pm 4.8 *$ \\
\hline
\end{tabular}

Values are presented as mean \pm SEM. M: male; F: female; DFA: diffuse fibrosing alveolitis. $\mathrm{Pa}, \mathrm{O}_{2}$ : partial pressure of oxygen in arterialized blood. *: $\mathrm{p}<0.05$ vs control group.

\section{Methods}

\section{Study population}

Control group. The control group consisted of 10 nonsmoking volunteers (five females and five males) without pulmonary disease, who underwent fibreoptic bronchoscopy and bronchoalveolar lavage (BAL) (table 1). The bronchial anatomy and mucosa were macroscopically normal. Differential cell counts in the BAL fluid (BALF) [17] and results of lung function tests [18] were within the normal range in all control subjects.

Patients. Twenty patients (13 females and 7 males) presenting with clinical, functional and radiological signs of diffuse fibrosing alveolitis (DFA) were investigated [19-22]. All patients were nonsmokers. There was no evidence of hypersensitivity pneumonitis and no history of exposure to organic or inorganic dusts. The diagnosis was confirmed histologically by transbronchial biopsy in 12 patients, and by open lung biopsy in five, in whom the transbronchial specimen was inconclusive. Three patients refused open lung biopsy when transbronchial biopsy had not been diagnostic. Although histological confirmation was lacking in these three patients, they were included in the study because there were typical findings of fibrosing alveolitis according to the above cited criteria and during follow-up. There was a significant restrictive ventilation pattern and impairment of the alveolar gas exchange as compared to the control group (table 1). All patients had been off treatment for at least 4 weeks when BAL was performed. The study protocol was approved by the local Ethics Committee. Informed consent was obtained from all control subjects and patients.

\section{Bronchoalveolar lavage}

BAL was performed in all controls and patients as described previously [17, 23]. A fibreoptic bronchoscope was wedged in a subsegmental bronchus and five serial infusions and aspirations were performed, each of $20 \mathrm{~mL}$ sterile saline $(0.9 \% \mathrm{NaCl})$. This procedure was performed for the middle lobe, the lingula and the left upper lobe. The fluid recovered was pooled, filtered through sterile gauze, centrifuged at $300 \times \mathrm{g}$ for $10 \mathrm{~min}$. An aliquot of the supernatant was analysed immediately for total glutathione (GSHtot). The cells were resuspended in phosphate buffered saline (PBS). Total cell counts were measured by means of a Coulter counter. Mean percentages of alveolar macrophages, neutrophils, eosinophils, lymphocytes, and mast cells were determined from slide preparations stained with May-Grünwald Giemsa stain, counting 600 cells.

\section{GSH-oxidation assay}

Preparation of bronchoalveolar inflammatory cells (BAcells). BA-cells obtained by BAL were cultured in a standard medium (RPMI 1640, Sigma) using 6-well, flatbottomed, plastic culture dishes (Falcon, NJ, USA) as described previously [10, 24-27]. After incubation for $30 \mathrm{~min}$ at $37^{\circ} \mathrm{C}$ with $5 \% \mathrm{CO}_{2}$, non adherent cells were removed by washing five times with Hank's balanced salt solution (HBSS) at $37^{\circ} \mathrm{C}$. The fractions of the washing-procedures were pooled and the number of cells removed was counted (MD-Kova Raster 10, Madaus, Köln, FRG). This method allows the generation of BA-cell monolayers consisting mainly of alveolar macrophages $[26,27]$. In our experiments, macrophage enrichment was $>95 \%$. A more detailed analysis of the residual cells was performed in four controls and six patients. After differentiating the cells in the pooled washing fractions, we were able to calculate the percentages of the residual cells, which did not differ significantly between controls and patients with respect to neutrophils $(0.83 \pm 0.51$ vs $1.44 \pm 0.77 \%)$, eosinophils $(0.21 \pm 0.11$ vs $0.56 \pm 0.31 \%)$, and lymphocytes $(1.41 \pm 0.72$ vs $1.01 \pm 0.62 \%)$.

Measurement of GSH-oxidation. The BA-cell cultures were incubated in HBSS (Sigma, USA) containing 50 $\mu \mathrm{M}$ GSH $\pm 160 \mathrm{nM}$ phorbol myristate acetate (PMA) (Sigma, USA) at $37^{\circ} \mathrm{C}$ with $5 \% \mathrm{CO}_{2}$. Blanks, i.e. incubation medium without cells present, were processed in exactly the same way. After $1 \mathrm{~h}$, the supernatant was removed and catalase (Sigma, USA) was added to a final concentration of $80 \mathrm{U} \cdot \mathrm{ml}^{-1}$ to stop $\mathrm{H}_{2} \mathrm{O}_{2}$-dependent reactions [28]. The samples were mixed with 5,5'-dithiobis(2-nitrobenzoic acid) (DTNB) (Serva, Heidelberg, FRG), final concentration $250 \mu \mathrm{M}$, and after $5 \mathrm{~min}$ of incubation the absorption was measured at $412 \mathrm{~nm}$ (Lambda 19 Spektrometer, Perkin Elmer, Überlingen, FRG). The GSH concentration was calculated using a 4-point standard curve $(75,56.25,37.5$ and $18.75 \mu \mathrm{M})$. From the decrease of the GSH concentration in the presence of BA-cells (+/-PMA) as compared to the blanks (no cells present) we calculated the nMoles of GSH which were oxidized by $10^{6}$ BA-cells $\cdot h^{-1}\left(\mathrm{nMol} \cdot 10^{-6} \mathrm{BA}-\right.$ cells $\left.^{-1} \cdot{ }^{-1}\right)$. For the calculations the number of adherent cells was used.

All measurements were performed in duplicate, variation was less than $2 \%$. 


\section{Quantification of ELF}

The volume of epithelial lining fluid was quantified by the urea method [29]. Concentrations of urea in BALF and serum were measured with the Urea Nitrogen 65UV Kit (Sigma Chemical, St. Louis, MO, USA).

\section{Measurement of total glutathione}

Total glutathione $(\mathrm{GSH}$ tot $=\mathrm{GSH}+2$ glutathione disulphide (GSSG)) was measured with modifications as described previously [30-33]. Immediately after BAL, $100 \mu 1$ of the BALF supernatant (centrifuged at 3,000 $\times \mathrm{g}$ for $10 \mathrm{~min}$ ) was mixed with $1.1 \mathrm{ml}$ of $0.1 \mathrm{M}$ sodium phosphate buffer, $\mathrm{pH} 7.0$, containing $1 \mathrm{mM}$ ethylenediamine tetra-acetic acid (EDTA), $0.2 \mathrm{mM}$ NADPH, 63.5 $\mu \mathrm{M}$ DTNB, and $4 \mathrm{U} \cdot \mathrm{mL}^{-1}$ glutathione reductase (all chemicals from Sigma, St. Louis, MO, USA). The rate of reduction of DTNB was recorded spectrophotometrically at a wavelength of $412 \mathrm{~nm}$. The GSHtot concentration within the BALF sample was calculated by using an internal standard of $0.84 \mu \mathrm{M}$ GSH. All measurements were performed in triplicate, the variation was less than $3 \%$.

\section{Measurement of glutathione disulphide (GSSG)}

BALF GSSG was determined according to the method described by ADAMs et al. [31]. BALF supernatants (centrifuged at $3,000 \times \mathrm{g}$ for $5 \mathrm{~min}$ ) were mixed with an equal volume of $10 \mathrm{mM}$ N-ethylmaleimide (NEM) in 0.1 $\mathrm{M}$ potassium phosphate buffer, $\mathrm{pH} 6.5$, containing 17.5 mM EDTA. Two hundred and fifty microlitres of the mixture was passed through a SEP-PAK $\mathrm{C}_{18}$ cartridge (Waters Associates, Milford, MA, USA) that had been prewashed with $3 \mathrm{ml}$ methanol followed by $3 \mathrm{~mL}$ aqua bidest. GSSG was eluted from the column with $1 \mathrm{~mL}$ of $0.1 \mathrm{M}$ potassium phosphate buffer, $\mathrm{pH} 7.5,5 \mathrm{mM}$ EDTA. Seven hundred and fifty microlitres of the eluate were added to $250 \mu \mathrm{L}$ potassium phosphate buffer, $\mathrm{pH} 7.5$, with $5 \mathrm{mM}$ EDTA, $800 \mu \mathrm{M}$ DTNB, $2 \mathrm{U} \cdot \mathrm{mL}^{-1}$ glutathione reductase, and $1 \mathrm{mM} \mathrm{NADPH}$. The rate of reduction of DTNB was recorded spectrophotometrically at 412 nM. Standards of GSSG (Boehringer, Mannheim, FRG) of known concentrations $(0.25-4 \mu \mathrm{M})$ were processed exactly as the BALF samples and were used to generate standard curves.

\section{Methionine sulphoxide content of BAL proteins}

The relative content of oxidized methionine residues (methionine sulphoxide, $\operatorname{Met}(\mathrm{O})$ ) of BALF proteins was determined as described previously $[11,15,16]$. Briefly, $2 \mathrm{~mL}$ aliquots of BALF were dialysed and lyophilised, then dissolved in $75 \%$ (vol/vol) formic acid. By cyanogen bromide $(\mathrm{CNBr})$ treatment, methionine (Met) residues are converted to homoserine and homoserine lactone, whereas $\operatorname{Met}(\mathrm{O})$ is stable. The $\mathrm{CNBr}$-treated proteins were hydrolysed with $6 \mathrm{M} \mathrm{HCl}$. In the presence of $5 \mathrm{mM}$ dithioerythritol at $110^{\circ} \mathrm{C}$ under vacuum for $48 \mathrm{~h}$. Under these conditions, $\operatorname{Met}(\mathrm{O})$ was quantitatively reduced to Met. After precolumn derivatization with orthophthalaldehyde (Pierce, Rockford, IL, USA), the samples were subjected to amino acid analysis by reversed-phase high-performance liquid chromatography (LKB, Freiburg, FRG). Results are presented as $\operatorname{Met}(\mathrm{O})$ in percentage of total methionine $(=\operatorname{Met}+\operatorname{Met}(\mathrm{O}))$.

\section{Statistics}

Data are expressed as the arithmetic mean and standard error of the mean (SEM). For statistical analysis the Mann-Whitney test for independent samples was employed. Correlation coefficients were determined by Pearson's test. For differences between groups and for correlation coefficients between variables, a p-value of less than 0.05 was considered significant with the twotailed test. The statistical computations were performed with the aid of SPSS/PC+ software.

\section{Results}

\section{BAL total and differential cell counts}

The results of BAL differential cell counts are shown in table 2. There was a significantly elevated total cell count in the DFA group and the differential cell count showed an intense, predominantly neutrophilic alveolitis as compared with the controls. The percentage of eosinophils was also increased. Lymphocytes and mast cells did not differ significantly from the control group.

\section{BA-cell oxidative activity}

To test whether the decrease of the GSH concentration in the incubation medium was due to oxidation, parallel measurements of GSH and GSSG concentrations in the supernatants were performed in a series of 13 individuals. As shown in figure 1, the decrease of GSH and increase of GSSG corresponded to the equation (2 GSH $\rightarrow$ GSSG) indicating that extracellular GSH

Table 2. - BAL differential cell counts of controls and patients with diffuse fibrosing alveolitis (DFA)

\begin{tabular}{lcc}
\hline & $\begin{array}{c}\text { Control group } \\
\mathrm{n}=10\end{array}$ & $\begin{array}{c}\text { DFA patients } \\
\mathrm{n}=20\end{array}$ \\
\hline Total cell count $\times 10^{6}$ & $22.9 \pm 4.3$ & $39.0 \pm 8.6^{*}$ \\
Alveolar macrophages $\%$ & $91.9 \pm 0.7$ & $67.2 \pm 4.5^{*}$ \\
Neutrophils \% & $2.7 \pm 0.5$ & $15.5 \pm 5.8^{*}$ \\
Eosinophils \% & $0.7 \pm 0.2$ & $6.0 \pm 2.7^{*}$ \\
Mast cells \% & $0.0 \pm 0.0$ & $0.4 \pm 0.2$ \\
Lymphocytes \% & $4.6 \pm 0.4$ & $10.9 \pm 4.7$ \\
\hline
\end{tabular}

Values are presented as mean \pm SEM. $*: \mathrm{p}<0.05$ vs control group. 


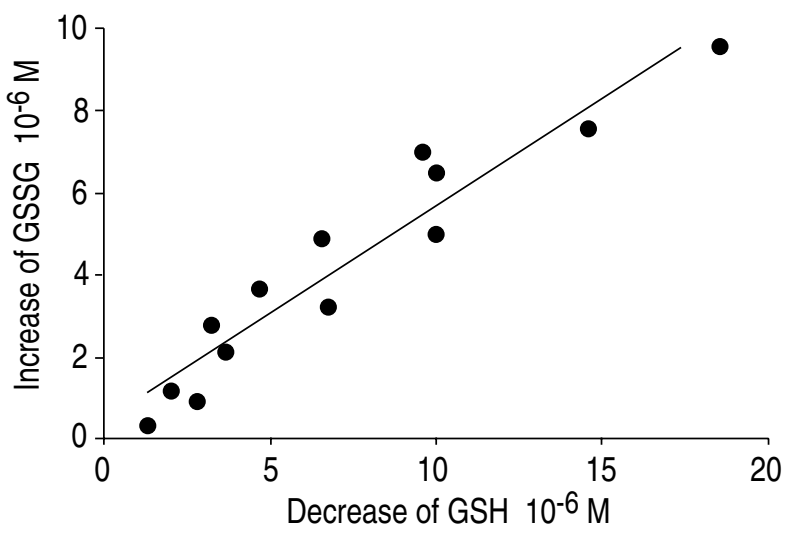

Fig. 1. - Relationship between the decrease of the GSH and increase of the GSSG concentration within the incubation median $(r=0.97 ; n=13$; $\mathrm{p}<0.001)$. GSH: reduced glutathione; GSSG: glutathione disulphide.

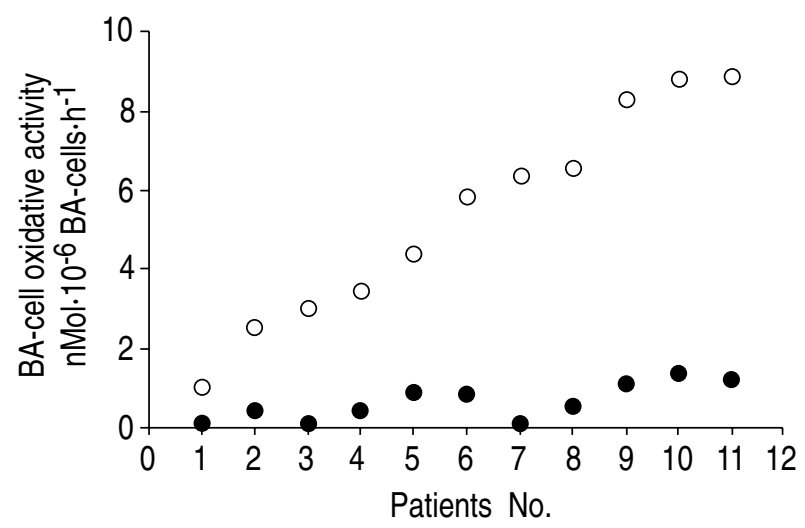

Fig. 2. - Eleven individuals were tested and ranked according to the spontaneous oxidative activity of their BA-cells $(O)$. If catalase $(160$ $\mathrm{U} \cdot \mathrm{mL}^{-1}$ ) was added to the assay, oxidative activity was almost completely inhibited in all cases $(\bullet)$. BA-cell: bronchoalveolar inflammatory cells.

is not oxidized to products other than the disulphide. GSH was not imported into or exported from the cells because total glutathione remained constant. Moreover, in a series of 11 patients, we found that GSH oxidation was almost completely inhibited by adding $160 \mathrm{U} \cdot \mathrm{ml}^{-1}$ catalase to the assay before starting the incubation (fig. 2 ). These experiments suggest that the observed GSHoxidation is almost completely due to hydrogen peroxide released from cultivated human BA-cells. Only a small amount of catalase-insensitive GSH oxidation occurred, which might be ascribed to reactive oxygen metabolites (ROMs), such as hypochlorous acid released from residual polymorphonuclear leucocytes (PMNs) within the BA-cell cultures.

Significantly increased amounts of extracellular GSH were oxidized by cultivated BA-cells from patients with DFA as compared with the control group (fig. 3). The spontaneous rate of $\mathrm{GSH}$ oxidation was $0.9 \pm 0.2$ $\mathrm{nMol} \cdot 10^{-6} \mathrm{BA}-\mathrm{cell}_{\mathrm{s}} \cdot \mathrm{h}^{-1}$ in the control group and $4.0 \pm 1.1$ $\mathrm{nMol} \cdot 10^{-6} \mathrm{BA}$-cells $\cdot \mathrm{h}^{-1}$ in the DFA group $(\mathrm{p}<0.05)$. With PMA stimulation, the absolute difference between controls and patients was even more pronounced: $1.8 \pm 0.3$ vs $6.3 \pm 1.8 \mathrm{nMol} \cdot 10^{-6} \mathrm{BA}-$ cells $\cdot \mathrm{h}^{-1}(\mathrm{p}<0.05)$.

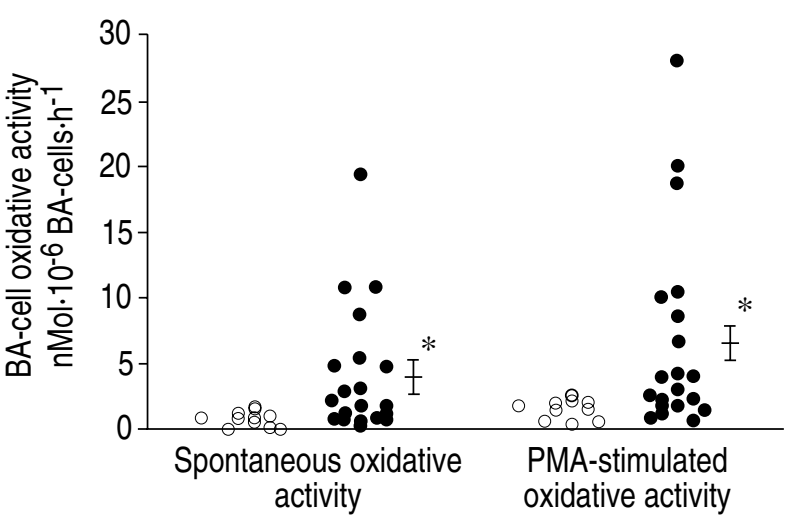

Fig. 3. - Spontaneous and PMA stimulated oxidative activity of BAcells from patients with DFA $(\mathrm{n}=20)(\bullet)$ was significantly $(\mathrm{p}<0.05)$ increased compared with the control group $(n=10)(O) . \Psi$ : mean \pm SEM for DFA patients. *: $\mathrm{p}<0.05$ vs control. DFA: diffuse fibrosing alveolitis; PMA: phorbol myristate acetate; BA-cells: bronchoalveolar inflammatory cells.

Table 3. - Glutathione concentration and form in ELF

\begin{tabular}{lcc}
\hline & $\begin{array}{c}\text { Control group } \\
(\mathrm{n}=10)\end{array}$ & $\begin{array}{c}\text { DFA patients } \\
(\mathrm{n}=20)\end{array}$ \\
\hline ELF recovered $\mathrm{mL}$ & $0.86 \pm 0.04$ & $1.24 \pm 0.08^{*}$ \\
Total GSH $\mu \mathrm{M}$ & $568 \pm 45$ & $285 \pm 20^{*}$ \\
GSH reduced $\mu \mathrm{M}$ & $506 \pm 53$ & $224 \pm 19^{*}$ \\
GSSG $\mu \mathrm{M}$ & $31.2 \pm 6.5$ & $30.7 \pm 6.3$ \\
GSSG:GSH ratio & $0.06 \pm 0.02$ & $0.14 \pm 0.03^{*}$ \\
\hline
\end{tabular}

Values are presented as meantsEM. ELF: epithelial lining fluid; DFA: diffuse fibrosing alveolitis; GSH: reduced glutathione; GSSG: glutathione disulphide. *: $\mathrm{p}<0.05$ vs control group.

\section{Glutathione in the ELF}

Table 3 summarizes the results of the GSH and GSSG measurements calculated for the recovered ELF volume, which was increased in the patient group. The levels of total GSH and reduced GSH were significantly decreased in the DFA patients, whereas the GSSG concentration was similar in controls and patients. The GSSG: GSH ratio was significantly increased in the patient group. Moreover, there was a significant positive correlation between the BA-cell oxidative activity and the GSSG: GSH ratio in the ELF (fig. 4). Interestingly, neither the percentage of BAL neutrophils $(r=0.29 ; n=20 ; p=0.21)$ nor the percentage of BAL alveolar macrophages correlated significantly with the GSSG:GSH ratio $(\mathrm{r}=0.29$; $\mathrm{n}=20 ; \mathrm{p}=0.21$ and $\mathrm{r}=0.25 ; \mathrm{n}=20 ; \mathrm{p}=0.29$; respectively).

\section{$\operatorname{Met}(O)$ content of alveolar proteins}

The $\operatorname{Met}(\mathrm{O})$ content of the BAL derived proteins was significantly increased in the patients with DFA (7.93 \pm $0.73 \%)$ compared to the control subjects $(4.18 \pm 0.74 \%)$ $(\mathrm{p}<0.05)$. There was no correlation between $\operatorname{Met}(\mathrm{O})$ and the spontaneous or PMA-stimulated oxidative activity of cultured BA-cells, measured in terms of GSH oxidation ( $p>0.05)$. However, significant inverse correlations existed between the $\operatorname{Met}(\mathrm{O})$ content of the alveolar proteins and the concentrations of GSHtot $(r=-0.71 ; n=20$; $\mathrm{p}<0.05)$ (fig. 5) and of GSH (r=-0.69; $\mathrm{n}=20$; $\mathrm{p}<0.05)$ in 


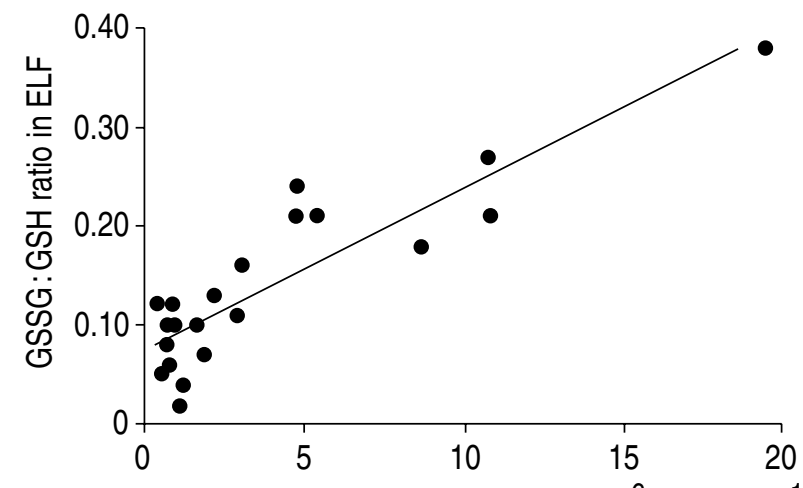

Spontaneous oxidative activity $\mathrm{nMol} \cdot 10^{-6} \mathrm{BA}$-cells $\cdot \mathrm{h}^{-1}$

Fig. 4. - The spontaneous oxidative activity of cultured BA-cells correlates positively with the GSSG:GSH ratio within the epithelial lining fluid (ELF) in the DFA group $(\mathrm{r}=0.87 ; \mathrm{n}=20 ; \mathrm{p}<0.01)$. For abbreviations see legends to figures $1-3$.

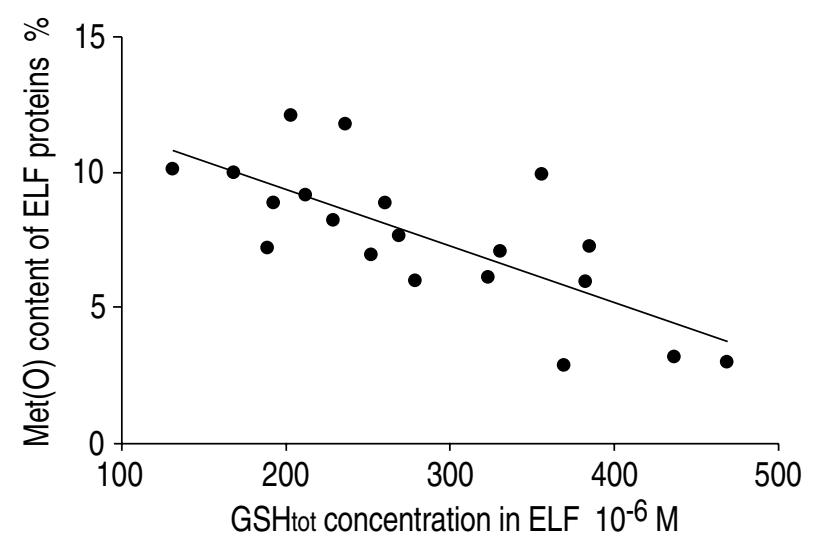

Fig. 5. - Significant inverse correlation between the GSHtot concentration in ELF and the Met $(\mathrm{O})$ content of the ELF proteins in DFA $(r=-0.71 ; n=20 ; p<0.01)$. GSH tot: total glutathione; $\operatorname{Met}(\mathrm{O})$ : methionine sulphoxide; ELF: epithelial lining fluid; DFA: diffuse fibrosing alveolitis.

the ELF. A significant positive correlation was observed between $\operatorname{Met}(\mathrm{O})$ and the percentage of BAL neutrophils in the DFA group $(\mathrm{r}=0.57 ; \mathrm{n}=20 ; \mathrm{p}<0.05)$.

\section{Discussion}

Fibrosing alveolitis is a chronic inflammatory disease of the lower respiratory tract characterized by accumulation of mononuclear and polymorphonuclear phagocytes within the alveolar walls [21, 22]. The release of highly reactive oxygen metabolites from these cells is known to be markedly increased, resulting in an excess oxidant stress [9-11,34]. This oxidant burden faces a diminished antioxidant defence, because reduced glutathione, the major antioxidant molecule within the ELF of the lower respiratory tract $[33,35]$, is significantly decreased in the DFA patients (table 3 ). This finding of our present study confirms reports from other investigators describing a glutathione deficiency in the ELF of patients with idiopathic pulmonary fibrosis [12-14]. However, little is known about the interaction of oxidants released from alveolar phagocytes and extracellular GSH in vivo.
In the present study, we provide evidence that ROMs released from human bronchoalveolar inflammatory cells are able to oxidize extracellular GSH in vitro. In contrast to other assays, which measure the production and/ or release of oxidants from phagocytes by reduction of cytochrome C [36] or oxidation of phenol red [37], the GSH-oxidation assay applied in this study was developed to mimic the in vivo situation by measuring the oxidative effect using GSH as a pathophysiologically relevant substrate. It remains, however, difficult to directly transfer the in vitro results of BA-cell oxidative activity to the in vivo situation, because changes of phenotype and function may occur when these cells are cultured [24]. Since the cells from controls and patients were processed in exactly the same way, there is strong evidence that BA-cells are capable of oxidizing increased amounts of GSH in DFA and may, thereby, contribute to the excess oxidative stress in vivo. The positive correlation observed between the spontaneous rate of GSH oxidation by cultured BA-cells and the GSSG:GSH ratio in ELF from patients with DFA (fig. 4) supports the concept that ROMs released from BA-cells contribute to the oxidation of extracellular GSH in the human lung. In contrast, the percentages of BAL neutrophils or alveolar macrophages were not significantly related to the GSSG:GSH ratio, indicating that the measurement of cell function with the GSH-oxidation assay is more closely related to biochemical effects in vivo than cell numbers.

As recently reported, the $\operatorname{Met}(\mathrm{O})$ content of ELF proteins reflects one important aspect of the in vivo effects of ROMs in ELF of patients with DFA [11, 16]. In good agreement with previous reports $[11,16], \operatorname{Met}(0)$ was significantly elevated in DFA patients as compared to the control group in this study. However, the $\operatorname{Met}(\mathrm{O})$ content of BAL proteins and the oxidative activity of cultured BA-cells measured in terms of GSH oxidation did not correlate significantly. In contrast, $\operatorname{Met}(\mathrm{O})$ formation in alveolar proteins was positively correlated with the percentage of BAL neutrophils, confirming similar results of previous studies $[11,16]$. There is experimental evidence indicating that methionine residues are efficiently oxidized by products of the myeloperoxidase $/ \mathrm{H}_{2} \mathrm{O}_{2} /$ chloride system, such as hypochlorous acid and chloramines, whereas superoxide anions, hydroxyl radicals, and hydrogen peroxide are far less effective [38]. Therefore, the positive correlation between the $\operatorname{Met}(\mathrm{O})$ content of BAL proteins and the percentage of BAL neutrophils is probably explained by the neutrophils' ability to release myeloperoxidase, which is necessary to form hypochlorous acid and chloramines, which in turn efficiently oxidize methionine residues of BAL proteins. In contrast, alveolar macrophages, which were the predominant cell type in the BA-cell cultures, are devoid of myeloperoxidase and, thus, unable to oxidize significant amounts of methionine. This may explain the absence of a direct relationship between BA-cell oxidative activity and $\operatorname{Met}(\mathrm{O})$ formation.

Interestingly, in this study, $\operatorname{Met}(\mathrm{O})$ correlated inversely with GSHtot (fig. 5) and with GSH. Consequently, a decrease of the GSHtot or GSH concentration in the ELF is associated with an increased $\operatorname{Met}(\mathrm{O})$ content of 
the ELF proteins. This result supports the assumption that GSH acts as an antioxidant at its physiological concentration in vivo.

Our data are thus complementary to findings of CANTIN et al. [33] indicating that GSH in physiological concentrations protects lung parenchymal cells against oxidative injury. Moreover, because of the inverse correlation between BA-cell oxidative activity and GSSG:GSH ratio in this study, it seems reasonable to assume that BA-cell oxidative activity, which mainly represents hydrogen peroxide release from alveolar macrophages, causes a significant impairment of the antioxidant screen of the lung, allowing oxidative damage as demonstrated by an increase of $\operatorname{Met}(\mathrm{O})$. As a consequence of these findings, it seems rational to correct the oxidant/antioxidant imbalance by increasing the GSH concentration in the lung as a therapeutic strategy in patients with diffuse fibrosing alveolitis.

Acknowledgements: The authors wish to thank A Neuber, L. Leuschel and A. Allmeling for expert technical assistance.

\section{References}

1. Badwey JA, Karnovsky ML. Active oxygen species and the functions of phagocytic leukocytes. Ann Rev Biochem 1970; 49: 695-726.

2. Fridovich I. The biology of oxygen radicals: the superoxide anion is an agent of oxygen toxicity: the superoxide dismutases provide an important defense. Science 1988; 201: 875-879.

3. Weiss SJ. Tissue destruction by neutrophils. N Engl J Med 1989; 320: 365-376.

4. Schraufstätter IU, Cochrane CG. Oxidants: types, sources, and mechanisms of injury. In: Crystal RG, West JB, eds. The Lung. New York, Raven Press, 1991; pp. 1803-1810.

5. Greenwald RA, Moy WW. Inhibition of collagen gelatin by action of superoxide radical. Arthritis Rheum 1979; 22: 251-259.

6. Greenwald RA, Moy WW. Effects of oxygen-derived free radicals on hyaluronic acid. Arthritis Rheum 1980; 23: 455-463.

7. Weiss SJ, Peppin G, Ortiz X, Ragsdale C, Test ST. Oxidative autoactivation of latent collagenase by human neutrophils. Science 1985; 227: 747-749.

8. Martin WJ II, Gadek JE, Hunninghake GW, Crystal RG. Oxidant injury of lung parenchymal cells. J Clin Invest 1981; 68: 1277-1288.

9. Cantin AM, North SL, Fells GA, Hubbard RC, Crystal RG. Oxidant-mediated epithelial cell injury in idioathic pulmonary fibrosis. J Clin Invest 1987; 79: 1665-1673.

10. Clement A, Chadelat K, Masliah J, et al. A controlled study of oxygen metabolite release by alveolar macrophages from children with interstitial lung disease. Am Rev Respir Dis 1987; 136: 1424-1428.

11. Behr J, Maier K, Krombach F, Adelmann-Grill BC. Pathogenetic significance of reactive oxygen species in diffuse fibrosing alveolitis. Am Rev Respir Dis 1991; 144: 146-150.

12. Cantin AM, Hubbard RC, Crystal RG. Glutathione deficiency in the epithelial lining fluid of the lower respiratory tract in idiopathic pulmonary fibrosis. Am Rev Respir Dis 1989; 139: 370-372.
13. Borok Z, Buhl R, Grimes GJ, et al. Effect of glutathione aerosol on oxidant-antioxidant imbalance in idiopathic pulmonary fibrosis. Lancet 1991; 338: 215-216.

14. Meyer A, Buhl R, Magnussen $\mathrm{H}$. The effect of oral $\mathrm{N}$-acetylcysteine on lung glutathione levels in idiopathic pulmonary fibrosis. Eur Respir J 1994; 7: 431436.

15. Maier K, Costabel U, Lenz AG, Leuschel L. Simultaneous determination of L-homoserine and L-homoserine lactone by reversed-phase liquid chromatography in acid hydrolysates of proteins after cyanogen bromide treatment. J Chromatogr 1989; 493: 380-387.

16. Maier K, Leuschel L, Costabel U. Increased levels of oxidized methionine in BAL fluid proteins from patients with idiopathic pulmonary fibrosis. Am Rev Respir Dis 1991; 143: 271-274.

17. Hunninghake GW, Gadek JE, Kawanami O, Ferrans VJ, Crystal RG. Inflammatory and immune processes in the human lung in health and disease: evaluation by bronchoalveolar lavage. Am J Pathol 1979; 97: 149-206.

18. European Coal and Steel Community. Standardized lung function testing. Report working party "standardization of lung function tests". Luxembourg, 1983. Bull Eur Physiopathol Respir 1983; 19 (Suppl. 5): 11-92.

19. Scadding JG, Hinson KFW. Diffuse fibrosing alveolitis (diffuse interstitial fibrosis of the lungs). Thorax 1967; 22: 291-304.

20. Dill J, Ghose JE, Landrigan P, MacKeen AD, Macneil AR. Cryptogenic fibrosing alveolitis. Chest 1975; 67: 411-416.

21. Crystal RG, Gadek JE, Ferrans VJ, Fulmer JD, Line BR, Hunninghake GW. Interstitial lung disease: current concepts of pathogenesis, staging and therapy. Am J Med 1981; 70: 542-568.

22. Crystal RG, Bitterman PB, Rennard SI, Hance AJ, Keogh BA. Interstitial lung diseases of unknown cause. $N$ Engl J Med 1984; 310: 154-166.

23. Behr J, Adelmann-Grill BC, Krombach F, Beinert T, Schwaiblmair M, Fruhmann G. Fibroblast chemotactic response elicited by native bronchoalveolar lavage fluid from patients with fibrosing alveolitis. Thorax 1993; 48: 736-742.

24. Senior RM, Campbell EJ, Villiger B. Obtaining and culturing human and animal alveolar macrophages. In: Adams DO, Edelson PJ, Koren HS, eds. Methods for Studying Mononuclear Phagocytes. New York, Academic Press, 1981; pp. 69-84.

25. Schaberg T, Haller H, Rau M, Kaiser D, Fassbender M, Lode H. Superoxide anion release induced by plateletactivating factor is increased in human alveolar macrophages from smokers. Eur Respir J 1992; 5: 387-393.

26. Schaberg T, Rau M, Stephan H, Lode H. Increased number of alveolar macrophages expressing surface molecules of the CD11/CD18 family in sarcoidosis and idiopathic pulmonary fibrosis is related to the production of superoxide anions by these cells. Am Rev Respir Dis 1993; 147: 1507-1513.

27. Baughman RP, Corser BC, Strohofer S, Hendricks D. Spontaneous hydrogen peroxide release from alveolar macrophages of some cigarette smokers. J Lab Clin Med 1986; 107: 233-237.

28. Suzuki Y, Lyall V, Biber TUL, Ford GD. A modified technique for the measurement of sulfhydryl groups oxidized by reactive oxygen intermediates. Free Rad Biol Med 1990; 9: 479-484.

29. Rennard SI, Basset G, Lecossier D, et al. Estimation of volume of epithelial lining fluid recovered by lavage 
using urea as marker of dilution. J Appl Physiol 1986; 60: $532-538$.

30. Akerboom TPM, Sies H. Assay of glutathione, glutathione disulfide, and glutathione mixed disulfides in biological samples. Methods Enzymol 1981; 77: 373-382.

31. Adams JD, Lauterburg BH, Mitchell JR. Plasma glutathione and glutathione disulfide in the rat: regulation and response to oxidative stress. J Pharmacol Exp Ther 1983; 227: 749-754.

32. Sies H, Akerboom T. Glutathione disulfide (GSSG) efflux from cells and tissue. Methods Enzymol 1984; 105: 445-451.

33. Cantin AM, North SL, Hubbard RC, Crystal RG. Normal alveolar epithelial lining fluid contains high levels of glutathione. J Appl Physiol 1987; 63: 152-157.

34. Strausz J, Müller-Quernheim J, Steppling H, Ferlinz R.
Oxygen radical production by alveolar inflammatory cells in idiopathic pulmonary fibrosis. Am Rev Respir Dis 1990; 141: 124-128.

35. Cantin AM, Begin R. Glutathione and inflammatory disorders of the lung. Lung 1991; 169: 123-138.

36. Pick E, Keisari Y. Superoxide anion and hydrogen peroxide production by chemically-elicited peritoneal macrophages: induction by multiple nonphagocytic stimuli. Cell Immunol 1981; 59: 301-318.

37. Pick E, Keisari Y. A simple colorimetric method for the measurement of hydrogen peroxide produced by cells in culture. J Immunol Methods 1980; 38: 161-170.

38. Maier KL, Matejkova E, Hinze H, Leuschel L, Weber $\mathrm{H}$, Beck-Speier I. Different selectivities of oxidants during oxidation of methionine residues in the $\alpha_{1}$-proteinase inhibitor. FEBS Lett 1989; 250: 221-226. 